\title{
Using optical coherence tomography to monitor effects of electromechanical reshaping in septal cartilage
}

\author{
Heather Chen, Lingfeng Yu*, Cyrus Manuel, Brian Jet-Fei Wong \\ From 2nd Scientific Meeting of the Head and Neck Optical Diagnostics Society \\ San Francisco, CA, USA. 23-24 January 2010
}

Electromechanical reshaping (EMR) of cartilage is a promising noninvasive technique with potential for broad application in reconstructive surgery. EMR involves applying direct current electrical fields to localized stress regions and then initiating a series of oxidation-reduction reactions, thus effecting a shape change. Previous EMR studies have focused on macroscopic structural measurements of the shape change effect or monitoring of electrical current flow. Only limited investigation of structural changes in the tissue at the histologic level have been performed, and not in real time. This study is the first to use optical coherence tomography (OCT) to examine structural changes in cartilage during EMR. Two platinum needle electrodes were inserted into fixed rectangular rabbit nasal septal cartilage specimens. The spectral domain OCT probe was then positioned above the anode needle. A constant voltage of $6 \mathrm{~V}$ was applied for 3 minutes, and images were obtained ( 8 frames/second). OCT was also performed in specimens undergoing dehydration under ambient conditions and during $\mathrm{pH}$ changes produced by the addition of $\mathrm{HCl}$, as both processes accompany EMR. The OCT data identified distinct findings among the three conditions, suggesting that EMR causes a much greater degree of reshaping on a molecular level than dehydration or a change in $\mathrm{pH}$ alone. OCT provides a means to gauge structural changes in the tissue matrix during EMR. The application of OCT to image the EMR process will add to our understanding of the mechanisms of action involved and potentially facilitate optimization of this process.

University of California, Irvine, USA

(c) 2010 Yu et al; licensee BioMed Central Ltd.
Published: 29 October 2010

doi:10.1186/1758-3284-2-S1-019

Cite this article as: Chen et al: Using optical coherence tomography to monitor effects of electromechanical reshaping in septal cartilage. Head \& Neck Oncology 2010 2(Suppl 1):O19.
Submit your next manuscript to BioMed Central and take full advantage of:

- Convenient online submission

- Thorough peer review

- No space constraints or color figure charges

- Immediate publication on acceptance

- Inclusion in PubMed, CAS, Scopus and Google Scholar

- Research which is freely available for redistribution

Submit your manuscript at www.biomedcentral.com/submit
C Biomed Central 